\title{
EVALUATION OF VEHICLE TAXATION IN THE REPUBLIC OF LATVIA BY THE METHOD OF VARIANT OPTIMIZATION USING RELATIVE SINGLE INDEXES
}

\author{
Alexey Leontyev ${ }^{1}$, Mg. oec., Galina Reshina ${ }^{2}$, Dr. oec. \\ 1,2Baltic International Academy, Latvia; ${ }^{1}$ University of Latvia, Latvia
}

\begin{abstract}
The European Commission has evaluated the consequences of the Latvian tax reform in 2018 and declared that the set target of decreasing tax burden for people with low income was not reached, yet the tax reform continuing implementation caused even greater social stratification. The goal of the study was to develop method for determining the rational tax on vehicles based on criteria of fairness and efficiency using an analytical approach. To develop such a method for vehicle taxation, relative single indexes approach as a part of method of variant optimization was used based on relative fuel equivalent coefficient. To analyse the current situation in Latvia and show possible ways of improving it, scenario analysis (three controlling cases) and mathematical modelling by using the developed method were carried out. Analysis of the first controlling case showed that the current situation in Latvia's vehicle taxation policy is not efficient enough from the point of the combination of fairness and efficiency. To improve the situation and achieve zone of optimum (the third controlling case) it is possible to shift tax burden partially from local taxpayers to taxpayers with foreign-registered vehicles. To comply with the recommendation of the European Commission, it is also recommended to set fairness as a primary criterion and make the system more favourable to the taxpayer (when operating in the zone of optimum). It can be achieved by using annual mileage as a base to determine the tax. If recommendations would be implemented partially, it is possible to reach the state (the second controlling case), where vehicle taxation is becoming optimal, yet any change in tax rates or procedures separately will lead to ineffective or unfair solutions. Overall the developed method allows to analyse and forecast most of the changes in vehicle taxation.
\end{abstract}

Key words: method of variant optimization, incomparability, tax rate, vehicle operation tax, free-rider problem.

JEL code: $\mathrm{H} 21, \mathrm{H} 22, \mathrm{H} 30$.

\section{Introduction}

Currently, Latvia's taxation system is being improved. At the same time, the directions of its reform are mainly related to solving problems that affect the interests of the two main participants in tax relations: the state and taxpayers. The reform of the country's tax system, which began in 2018, did not directly affect the vehicle operation tax, but this reform provided for a certain correction, which, of course, applies to all vehicle owners: both individuals and legal entities.

The European Commission, assessing the results of the tax reform, a year after its introduction, noted that it has not yet been possible to reduce inequality between different segments of the population, and made recommendations according to which it is necessary to reduce the level of taxation for low-income people in order to reduce social inequality (European Commission Recommendation, 2019). Therefore, for a comprehensive solution to this problem, it is necessary to develop a fair model of vehicle taxation, which at the same time would be effective.

It is necessary to notice, that any imprudent tax action, incorrect decision-making that is not based on estimates and does not have a clear idea of the expected results will lead to a reduction in state budget revenues and adversely affect the solvency and welfare of the population (Sproge I., 2010). Currently, decisions are made on an intuitive level - there is no description of analytical methods that allow quantifying the changes proposed by the European Commission and thus more accurately building the tax policy. Making decisions on an intuitive level is not optimal, it requires numerous subsequent adjustments, which is confirmed by the need for new tax reform or the introduction of significant corrective measures.

${ }^{1}$ Alexey Leontyev e-mail: kratovo490@mail.ru 
The goal was to develop method for determining the rational tax on vehicles based on criteria of fairness and efficiency using an analytical approach.

To reach the goal, the following tasks were set:

- to analyse normative enactments and scientific literature on the organization of vehicle taxation;

- to create relative single indicators of fairness and efficiency for determining the optimal tax burden;

- to carry out a graph-analytical analysis to identify the area of optimum (where the most appropriate tax burden located to comply with the set restrictions of fairness and efficiency);

- to develop recommendations to adjust current tax policy regarding vehicle taxation to comply with the rational tax.

The object of the study is the optimum of the vehicle taxation in Latvia, bounded by fairness and efficiency criteria.

The used methods included:

- analysis of primary and secondary data - this part involves gathering and transformation of real data to relative fuel equivalent values, which makes the whole research more scalable;

- mathematical modelling - used for describing a potential transitional situation, that can happen when recommended measures to improve the tax policy regarding vehicle taxation is not implemented in the full extent;

- scenario analysis - represented by analysis of current situations and several possible future situations, that could be achieved by introducing some changes to the existing tax system;

- relative single indexes approach - unique method, used for mathematical calculations with criteria, herein fairness and efficiency.

\section{Research results and discussion}

As part of the study, the sources of normative, reference and scientific literature on the organization of vehicle taxation in Latvia and other countries of the European Union were analysed. Based on the analysis of regulatory documentation the current method of calculating the vehicle operation tax in the Republic of Latvia was analysed, identified shortcomings and areas for improving it.

Vehicles in most countries of the world are subject to taxation, bringing a certain share of money to the state budget. The main source of revenue generation in the budget system of the Republic of Latvia is taxes and receipts, in particular, the vehicle operation tax (Law on the Vehicle Operation Tax, 2011). This tax, like every other, is individual, since it assumes its own legal structure.

At the same time, since 2020 in Latvia, several taxes are addressed to owners of vehicles (Natural Resources Tax Law, 2006; Regulations Regarding Recycling, 2011; Value Added Tax Law, 2013; On Personal Income Tax, 1994; Enterprise Income Tax Law, 2018; Law on the Road User Charge, 2014).

The document published by the Ministry of Finance of the Republic of Latvia "Guidelines for state tax policy for 2018-2020" indicates that a number of measures were planned to mitigate the negative impact of the tax reform (which was put into effect from the beginning of 2018), including the following in the aspect of this study: increasing excise tax rates (including fuel for vehicles), limiting the rights to benefits, maintaining the current payment system for collecting tax on vehicle operation (Order of the Cabinet of Ministers, 2017).

Indeed, at the beginning of 2020 , the principle of levying a vehicle operation tax remains unchanged. 
Since January 2017, a tax has been imposed on vehicles with foreign licence plates travelling in Latvia, if their owners are persons whose place of residence is declared in Latvia (Law on the Vehicle Operation Tax, 2011). Many residents of Latvia registered their cars in Lithuania and Estonia in order to avoid paying the Latvian vehicle operation tax. At the same time, they used the road infrastructure along with other residents of the country.

To combat this phenomenon, amendments were adopted to the Road Traffic Law and to the Law on the Vehicle Operation Tax and Company Car Tax. According to them, owners of vehicles of categories M1 (passenger cars used for transportation of passengers, the number of seats of which, excluding the driver's seat, does not exceed eight seats) and N1 (vehicles intended for transportation of goods and whose gross weight does not exceed 3.5 tons), who have declared their place of residence in Latvia, when operating these vehicles, if they are registered abroad, are obliged to pay the following operating tax: for one day - 10 euros; for a month - 250 euros; for six months 600 euros; for a year -1000 euros. The penalty for evading this tax is between 140 and 400 euros.

This tax according to the Ministry of Transport for the first year after its introduction brought in the state budget a little less than 800,000 euros, then its amount began to decrease slightly, and the number of registered vehicles (CSDD - Vehicle statistic, 2020), compared to 2016, increases annually.

This method solved one of the so-called "free-rider problem", i.e. the situation when a consumer of a public good tries to avoid paying for it (Kharevich G. L., 2017).

Starting from January 1, 2020, the excise tax on fuel has been increased in Latvia. The rates of this tax and the objects of taxation are determined by the law of the Republic of Latvia "On Excise Duties" (On Excise Duties, 2004).

It should be noted that according to CSDD data as of 1 January, 2020, the average age of passenger cars registered in Latvia is 14.20 years, commercial vehicles - 11.97 years, and buses 12.51 years (CSDD - Vehicle statistic, 2020).

All this leads to the fact that for a part of the population, the maintenance and operation of vehicles, based on their total costs, becomes difficult. In this regard, when introducing taxes and fees related to the operation of a vehicle, it is advisable to conduct special analytical studies.

Verovska L., Leontyev A. (2015) and Leontyev A. (2015), have proposed to use a system of relative single indexes for variant optimization used to determine the tax base.

Before carrying out variant optimization, it is necessary to determine the numerical values of relative single indexes that characterize the "fairness" and "efficiency" of the tax policy for each specific case and time period.

To determine terms fairness and efficiency - the classification of tax law principles according to A. Wagner is used, where efficiency principle is a part of fiscal function and principle of equity (or fairness) is part of social justice of taxation (Jarczok-Guzy M., 2017).

It is advisable to determine the numerical values of relative single indexes using this scheme:

$$
\begin{gathered}
K_{i j}=P_{i j} / P_{i, b l} \text { or } K_{i j}={ }^{P, b l} / P_{i j} \\
i=\overline{1, N} ; j=\overline{1, M},
\end{gathered}
$$

where:

- $K_{i j}$ - relative designation of relative single index;

- $P_{i j}$ - value of single index of researched characteristic (equity or efficiency);

- $P_{i, b l}$ - value of single index taken as basic (possible) level; 
- $i$ - name of the estimated characteristic;

- $j$ - no. of variant;

- $N$ - the number of relative single indexes;

- $M$ - the number of researched variants.

In all cases, when determining the values of relative single indexes from the formulae (1), the one that corresponds to the improvement of the quality of the index system with an increase in the single index is selected.

When determining the optimal values of the vehicle operation tax from the point of view of the "efficiency" criterion of taxation, it is advisable to assign $P_{i, b}$ values after calculations made according to the CSDD data on the number and types of registered vehicles, taking into account the forecast of the dynamics of their change. Further, depending on the required share of funds received in the budget for the implementation of this tax, it is necessary to distribute the tax burden for specific types of transport, which will allow to select the necessary $P_{i, b}$ value.

Relative single indexes of "fairness" $K_{f j}$ and "efficiency" $K_{e j}$ are formed in such a way that their values, which lie in the range of values less than one, reflect an unacceptable value of quality (their characteristics), and acceptable values of indexes $K_{i j}$ are equal to or exceed one.

In accordance with the provisions set out in (Economic Commission for Europe, 2015), the EU has the opportunity to improve the efficiency of its economy and reduce greenhouse gas emissions from transport.

As a result of this program, the excise rate for lead-free petrol (the use of tetraethyl lead has been banned in the EU since 2000) increased from 476 euros per 1,000 litres to 509 euros. The excise tax on diesel fuel increased from 372 euros per 1,000 litres to 414 euros, and on liquefied gas used for refuelling vehicles-from 244 euros to 285 euros per 1,000 litres (On Excise Duties, 2004). As a result, when refuelling, in addition to VAT, the consumer pays the new price in accordance with the increased excise tax. It was assumed that after the increase in this excise tax, the price of a litre of petrol will increase by approximately 0.04 euros, diesel fuel by 0.05 euros, and liquefied gas by 0.03 euros. However, in fact, fuel prices in Latvia have increased more, and this is due not only to an increase in the excise tax, but also to an increase in the price of oil (at the end of November 2019, a barrel of oil cost slightly less than 61 euros, and at the beginning of 2020, its price increased to almost 69 euros).

At the same time, a situation arose that requires a separate study: fuel prices in Latvia at the beginning of 2020 were the highest among the countries of the Baltic region, even though the road tax is included in the cost of fuel in Lithuania. As a result, residents of border areas started refuelling in neighbouring countries. These budget losses in Latvia require a separate study. Budget losses are also related to the fact that residents of the country's regions bordering Russia and Belarus, having a simplified border crossing regime, refuel their vehicles abroad, where fuel prices are much lower. At the same time, customs regulations allow them to import into the territory of Latvia a vehicle with a fully filled tank and an additional 10 litres in a canister. Therefore, before rationing the vehicle operation tax rates and adjusting the excise tax rates, it is necessary to study the budget implications arising from the reduction of the total amount of fuel sold for vehicles in the territory of the Republic of Latvia.

Among other problems faced by vehicle owners in Latvia, there is an increase in the volume of bio-additives for diesel fuel from $5 \%$ to $7 \%$, and for 95 petrol from $5 \%$ to $10 \%$ (E10). However, not all petrol engines of vehicles can run on fuel with a high content of bio-additives (E10). This 
applies primarily to older vehicles. As already noted, the average age of passenger cars registered by CSDD in Latvia exceeds 14 years. To maintain the performance of their engines, owners will have to switch to a more expensive brand 98 petrol, which does not contain bio-additives.

As a result, owners of vehicles with low and medium incomes have to revise the mode of operation of their vehicles in the direction of its reduction.

According to studies in 2019, which estimated the amount of fuel for a vehicle that can be purchased for one average salary, conducted in 33 European countries, Latvia was in the 30 th place (Petrol availability rating, 2019).

This is one of the reasons why it is difficult for residents of Latvia to accept EU requirements for improving the environmental situation, which lead to higher fuel prices and an increased tax rate on vehicles that do not meet strict environmental standards.

The average annual cost of maintaining a used car in Latvia is between 500 and 600 euros (Berzins A., 2017). According to official data from the Latvian Central statistical bureau, the average salary in Latvia in 2018 after taxes was 737 euros, in 2019 it increased slightly, and as a result, the employee received about 800 euros (CSB, 2020).

In this study, the calculations were based on the conditional fuel equivalent, i.e. the maximum amount of fuel that can be purchased for an average salary in Latvia.

One of the options for a possible approach to the formation of a relative unit tax when assessing and assigning a vehicle operation tax was considered. After processing data on the most popular brands of passenger cars registered in Latvia (CSDD - Vehicle by manufacturer, 2020), it was found that in fuel equivalent, the owner of a passenger vehicle spends an average of 5 to 8 litres of petrol per month on the vehicle operation tax. At the same time, it would not be burdensome to spend no more than 7 litres of fuel per month on the tax under study.

In this situation, it is assumed that in order to replenish the budget, the state needs each owner to contribute at least 9 units of fuel equivalent to the budget on average. Based on these assumptions, table 1 was formed, and the relative single indexes of fairness and efficiency for different tax options for persons operating vehicles were calculated using formulas (1).

When analysing this optimization model, it turned out that the relative single indexes of fairness $K_{f j}$ and efficiency $K_{e j}$ that characterize the vehicle operation tax were incompatible (Fig. 1 ).

Table 1

\section{Determination of relative single indexes of fairness and efficiency} (first controlling case)

\begin{tabular}{|l|c|c|c|c|c|c|c|c|c|c|c|c|}
\hline No. of variant & $\mathbf{1}$ & $\ldots$ & $\mathbf{5}$ & $\mathbf{6}$ & $\mathbf{7}$ & $\mathbf{8}$ & $\mathbf{9}$ & $\mathbf{1 0}$ & $\mathbf{1 1}$ & $\ldots$ & $\mathbf{1 3}$ & $\mathbf{1 4}$ \\
\hline Pfj & 610 & $\ldots$ & 606 & 605 & 604 & 603 & 602 & 601 & 600 & $\ldots$ & 598 & 597 \\
\hline P f, bl & \multicolumn{10}{|c|}{605} \\
\hline K fj & 1.008 & $\ldots$ & 1.002 & 1.000 & 0.998 & 0.997 & 0.995 & 0.993 & 0.992 & $\ldots$ & 0.989 & 0.987 \\
\hline P ej & 2 & $\ldots$ & 6 & 7 & 8 & 9 & 10 & 11 & 12 & $\ldots$ & 14 & 15 \\
\hline P e, bl & \multicolumn{10}{|c|}{9} \\
\hline K ej & 0.222 & $\ldots$ & 0.667 & 0.778 & 0.889 & 1.000 & 1.111 & 1.222 & 1.333 & $\ldots$ & 1.556 & 1.667 \\
\hline
\end{tabular}

In such a situation, if it is impossible to change the calculation conditions, it is necessary to determine the importance of each criterion. If the relative single index of effectiveness $K_{e j}$ is given priority in the ranking, then option 8 or subsequent options located to the right of this option on the abscissa axis (to the right of point B) should be selected as acceptable. 


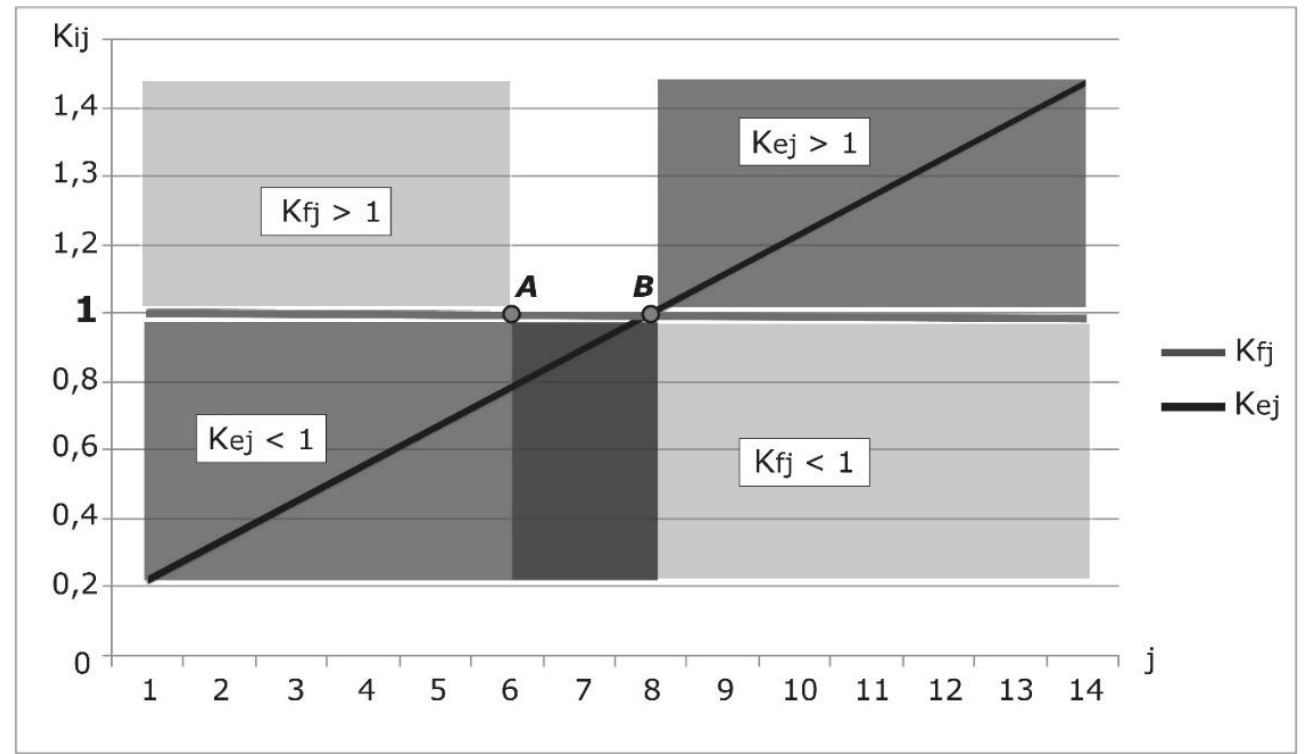

Source: created based on the authors' calculations

Fig. 1. Combined diagram of relative single indexes of fairness and efficiency (the first controlling case is incompatibility of requirements)

If priority is given to the relative single index of fairness $K_{f j}$, then acceptable values fall on options 1-6, located to the left of point A. It is possible that if the indexes are equally important, it will be necessary to make concessions on both criteria at the same time and choose the most appropriate solution. Ranking should be done using expert methods or, more preferably, using a probabilistic approach. The process of ranking and the use of the method of consecutive concessions in similar situations is shown in the works (Leontyev, 2015; Akhmetshin E. M. et al., 2019).

Several more possible situations were covered. If the vehicle operation tax calculated in fuel equivalent is sufficient for the budget in the amount of 8 units, and this amount will not be burdensome for vehicle owners (table 2), then the combined diagram shown in Fig. 1, is converted to the diagram shown in Fig. 2.

Table 2

\section{Determination of relative single indexes of fairness and efficiency (second controlling case)}

\begin{tabular}{|c|c|c|c|c|c|c|c|c|c|c|c|}
\hline No. of variant & $\mathbf{1}$ & $\ldots$ & $\mathbf{6}$ & $\mathbf{7}$ & $\mathbf{8}$ & $\mathbf{9}$ & $\mathbf{1 0}$ & $\mathbf{1 1}$ & $\mathbf{1 2}$ & $\mathbf{1 3}$ & $\mathbf{1 4}$ \\
\hline $\boldsymbol{P}_{\boldsymbol{f} \boldsymbol{j}}$ & 610 & $\ldots$ & 605 & 604 & 603 & 602 & 601 & 600 & 599 & 598 & 597 \\
\hline $\boldsymbol{P}_{\boldsymbol{f}, \boldsymbol{b l}}$ & \multicolumn{8}{|c|}{604} \\
\hline $\boldsymbol{K}_{\boldsymbol{f} \boldsymbol{j}}$ & 1.010 & $\ldots$ & 1.002 & 1.000 & 0.999 & 0.997 & 0.995 & 0.993 & 0.992 & 0.990 & 0.998 \\
\hline $\boldsymbol{P}_{\boldsymbol{e} j}$ & 2 & $\ldots$ & 7 & 8 & 9 & 10 & 11 & 12 & 13 & 14 & 15 \\
\hline $\boldsymbol{P}_{\boldsymbol{e}, \boldsymbol{b}}$ & \multicolumn{8}{|c|}{8} \\
\hline $\boldsymbol{K}_{\boldsymbol{e} j}$ & 0.250 & $\ldots$ & 0.875 & 1.000 & 1.125 & 1.250 & 1.375 & 1.500 & 1.625 & 1.750 & 1.875 \\
\hline
\end{tabular}

Source: created based on the authors' calculations 


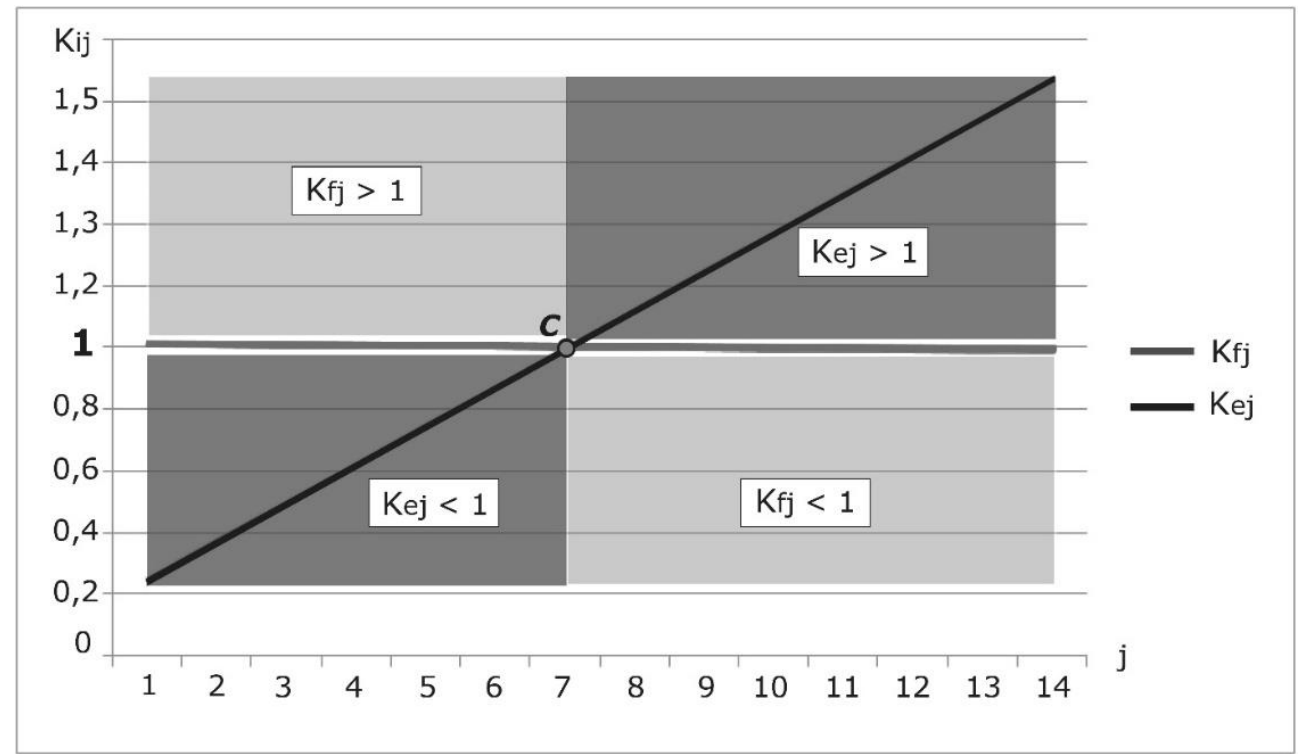

Source: created based on the authors' calculations

Fig. 2. Combined diagram of relative single indexes of fairness and efficiency (the second controlling case is the only solution)

In this case, one option that meets the criteria of fairness and effectiveness (7 option corresponding to point $C$ in Fig. 2) is available. It should be noted that the accuracy of this study is not in doubt when analysing past periods. In studies that cover the forecast period, there is always the possibility of changes in the economic environment that affect the combination of relative single indexes $K_{f j}$ and $K_{e j}$ that characterize the vehicle operation tax. Point $C$ on the combined diagram shows, that vehicle taxation becoming optimal, yet any change in tax rates or procedures separately will lead to ineffective or unfair solutions.

After adjusting the values taken as basic (reference) values, table 3 was compiled and the combined diagram was built again (Fig. 3). The resulting combination of relative single indexes is the most preferable, since it is not the only possible option, but the area of acceptable values located between the points $\mathrm{D}$ and $\mathrm{E}$ in the range of values $K_{f j}$ and $K_{e j}$ from one and higher.

Table 3

\section{Determination of relative single indexes of fairness and efficiency} (third controlling case)

\begin{tabular}{|c|c|c|c|c|c|c|c|c|c|c|c|}
\hline $\begin{array}{l}\text { No. of } \\
\text { variant }\end{array}$ & 1 & $\ldots$ & 4 & 5 & 6 & 7 & 8 & 9 & 10 & $\ldots$ & 14 \\
\hline$P_{f, b l}$ & 610 & $\ldots$ & 607 & 606 & 605 & 604 & 603 & 602 & 601 & $\ldots$ & 597 \\
\hline$K_{f j}$ & \multicolumn{11}{|c|}{602} \\
\hline $\boldsymbol{P}_{\mathrm{ej}}$ & 1.013 & $\ldots$ & 1.008 & 1.007 & 1.005 & 1.003 & 1.002 & 1.000 & 0.998 & $\ldots$ & 0.992 \\
\hline $\boldsymbol{P}_{e, b l}$ & 2 & $\ldots$ & 5 & 6 & 7 & 8 & 9 & 10 & 11 & $\ldots$ & 15 \\
\hline$K_{\text {ej }}$ & \multicolumn{11}{|c|}{7} \\
\hline$P_{f j}$ & 0.286 & $\ldots$ & 0.714 & 0.857 & 1.000 & 1.143 & 1.286 & 1.429 & 1.571 & $\ldots$ & 2.143 \\
\hline
\end{tabular}

Source: created based on the authors' calculations

To achieve optimum zone, which lies between points $D$ and $E$, it is recommended to establish a tax on the use of Latvian roads for owners of passenger cars that are not declared in Latvia. This applies to owners of passenger vehicles who come to the Republic of Latvia from countries that are part of the European Union or outside its borders. At the moment, they do not pay tolls for driving on Latvian roads. This tax is easy to implement, because Latvia has experience of collecting a similar tax, for example, from owners of cargo transport with a gross weight of more than $3000 \mathrm{~kg}$, and 
from vehicles registered outside of Latvia, whose owners have declared their place of residence on its territory. Similar taxes exist in a number of EU countries and are approximately equal to 12.5 euros for 10 days of road use, 18 euros for a month, and 60 euros for a year. Such actions at the same time will allow slightly to decrease a burden for local taxpayers, making it closer to the desired 7 relative litres of the tax burden, but it is not yet achieved, but tax burden could be redistributed on foreigners.

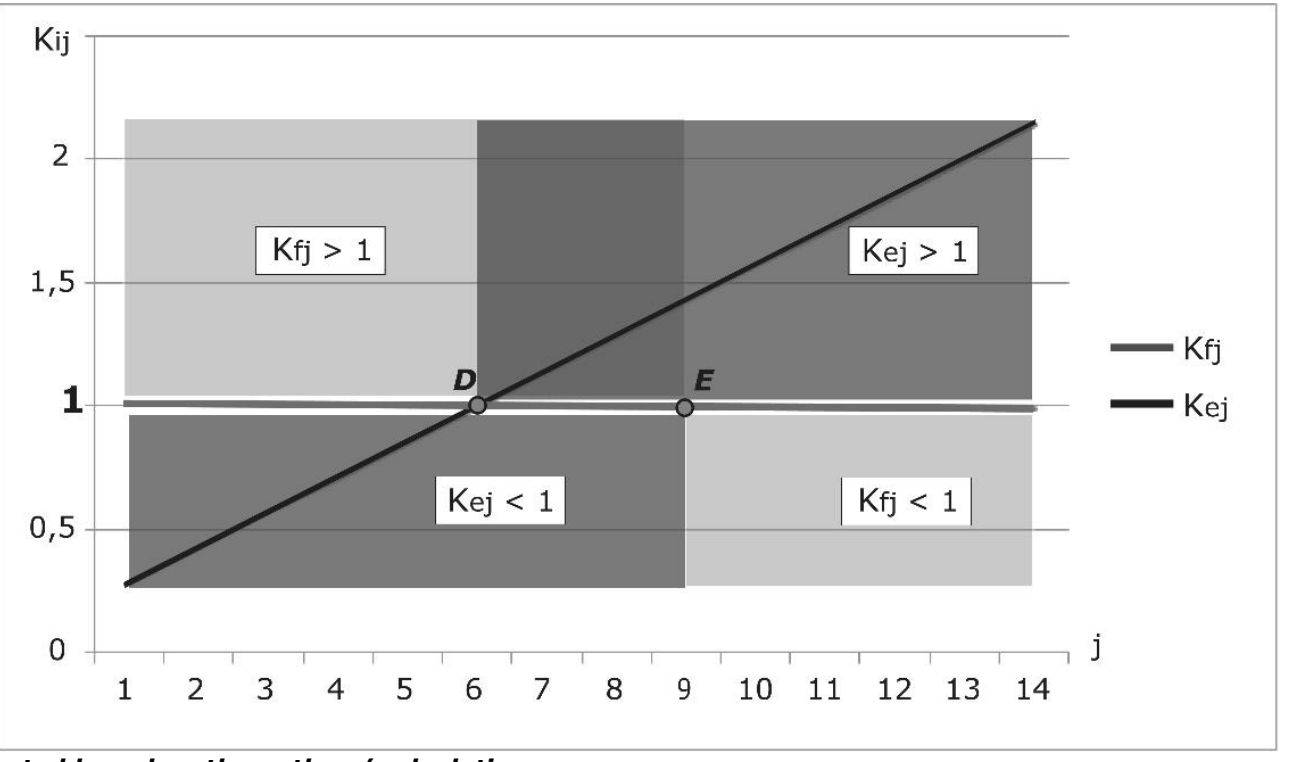

Source: created based on the authors' calculations

Fig. 3. Combined diagram of relative single indexes of fairness and efficiency (the third controlling case is a set of possible solutions)

If it is necessary to adjust the amount of fuel equivalent when searching for suitable solutions using the proposed combined diagram, the following options can be considered as a measure that allows the state to reduce the amount of tax burden imposed on persons who operate vehicles belonging to them.

While adjusting the tax in the optimum zone, it is advisable to establish a correlation with the vehicle's annual mileage. It can contribute to a fairer principle of charging a vehicle operation tax. When implementing this principle, those who drive less - pay less tax (except for owners of premium and sports cars). Gradation is also possible in terms of vehicle engine capacity. For example, only owners of vehicles with an engine capacity of up to $180 \mathrm{l} / \mathrm{s}$ may fall under this proposal, other vehicles are taxed at a fixed rate. Such changes will be inside of the optimum zone, yet they will set fairness as primary criterion, which will lead to decrease of poverty and social stratification, achieving the recommendation of the European Commission. If the global situation changes and economy will need extra tax revenues, the regulator will know to what extent tax rates or establishing of the new taxes in vehicle taxation could be carried out to be comfortable enough for the tax payer, not making taxpayer search for opportunities to use tax evasion.

Taxation of vehicles (including not only taxes, but also special charges on their owners) in Latvia is not currently in the comfort zone for a number of categories of taxpayers (the first controlling case). And most of this applies to people with low incomes who operate fairly old vehicles and persons who have a residence permit in Latvia, whose vehicles are permanently registered outside the European Union. The increase in excise tax rates not only makes positive sense, but also has negative onerous consequences for many taxpayers. At the same time, no administrative measures 
will ensure the completeness of tax revenues to the budget if the tax mechanism adopted by law is not adequate to the state of the economy and politics.

It should be noted that Latvia has successfully coped with the "free-rider problem" in relation to persons declared in Latvia whose vehicles are registered in other EU countries.

It is necessary to link tax administration with tax innovations. Otherwise, "tax holes" may appear, in which only those who have achieved virtuosity in avoiding taxes win, and the entire economy loses.

Using the methods of variant optimization and "tax prism" will allow to visualize the process of modelling various situations when searching for the fairest and most effective model of taxation of vehicle owners.

A complete rejection of the tax in question through its inclusion in the cost of petrol for Latvia is difficult to implement, since the analysis of fuel prices for the last three years shows that fuel prices in Latvia are somewhat higher in relation to Lithuania and Estonia. This, as already mentioned, leads to the fact that some car owners refuel their vehicles on the territory of these countries.

Fixing the value of the annual mileage of vehicles can be carried out both during technical inspection, and using special GPS navigation systems, or using special devices (How to control mileage, 2017).

At the same time, it is necessary to regulate the tax on vehicles registered in Latvia but used on the territories of other countries, as well as the cost of creating a system for collecting such taxes.

It should be noted that the Ministry of Transport has allocated about 16 million euros for the creation of similar systems in the Czech Republic. Within a few days, a team of IT specialists from the Czech Republic created and delivered a state service to the government for free, which was ordered by another company. As a result, the Czech Transport Minister was dismissed, since the creation of such services does not currently involve significant financial costs (For one weekend and free, 2020).

To select the optimal tax options related to the operation of vehicles, it is possible to additionally use the "tax prism" method proposed by Verovska L. and Leontyev. A. in 2017, which allows to visualize the process of selecting the most acceptable rates of the tax under study.

\section{Conclusions, proposals, recommendations}

1) The method of variant optimization using relative single indexes for optimal vehicle taxation is a powerful tool that could be used as an anchor to see the current situation and a consequence of possible changes in tax legislation. As a relative index used a relative coefficient of fuel equivalent basing on an average salary, which could show over time dynamic of the situation with the vehicle taxation.

2) The analysis of the controlling cases, acquired by the usage of the method of variant optimization using relative single indexes showed that in the first controlling case the tax policy efficiency is incomparable with fairness criterion, so it eventually leads to loss of budget revenues and at the same time stimulates impoverishment of the population. In the second controlling case there is only one optimal point, that complies with the criteria of fairness and efficiency. It should be used by state authorities to set appropriate taxes and adjust tax policy. In the third controlling case there is the area of optimal combination of fairness and efficiency. The government has wide amount of options of possible tax rates, that could be used to adjust tax policy and be a reference to a long-term planning. 
3) Latvia currently has incomparability zone, meaning the taxation of vehicles is not optimal for most of the taxpayer with low or average income. To move from the incomparability to the zone of optimum it recommended to establish a tax on the use of Latvian roads for owners of passenger cars that are not declared in Latvia. This applies to owners of passenger vehicles who come to the Republic of Latvia from countries that are part of the European Union or outside its borders. This tax is easy to implement, because Latvia has experience of collecting a similar tax, for example, from owners of cargo transport with a gross weight of more than $3000 \mathrm{~kg}$, and from vehicles registered outside of Latvia, whose owners have declared their place of residence on its territory.

4) When zone of optimum will be reached it is advisable to establish a correlation with the vehicle's annual mileage, which can contribute to a fairer principle of charging a vehicle operation tax. When implementing this principle, those who drive less - pay less tax (except for owners of premium and sports cars). Gradation is also possible in terms of vehicle engine capacity. For example, only owners of vehicles with an engine capacity of up to $180 \mathrm{l} / \mathrm{s}$ may fall under this proposal, other vehicles are taxed at a fixed rate. Such changes will be inside of the optimum zone, yet they will set fairness as primary criterion, which will lead to decrease of poverty and social stratification.

5) A complete rejection of the tax vehicle operation tax by including it in the price of petrol for Latvia is difficult to implement, because an analysis of fuel prices over the past three years shows that fuel prices in Latvia are slightly higher compared to Lithuania and Estonia. This leads to the fact that some car owners refuel their vehicles in these countries. Fixing the value of the annual mileage of vehicles can be carried out both during technical inspection, and using special GPS navigation systems, or using special devices. In this case, it is necessary to regulate the tax on vehicles registered in Latvia, but used in other countries, as well as the cost of creating a system for managing such taxes.

\section{Bibliography}

1. Akhmetshin E.M., Plaskova N.S., Iusupova I.I., Prodanova N.A., Leontyev A.N., Vasilev V.L. (2019). Dataset for Determining Rational Taxation Value with Incompatible Criteria of Economic Efficiency and Equity. Data in Brief, Volume 26, 104532, 11 p. https://doi.org/10.1016/j.dib.2019.104532.

2. Berzins A. (2017). BigBank Research - How Much Does the Maintenance of the Used Car Cost in Latvia? Retrieved: http://ru.focus.Iv/news/issledovanie-bigbank-skoljko-stoit-soderzhanie-poderzhanogo-avto-vlatvii?14999 Access: 25.01.2020.

3. CSB (Central Statistical Bureau) of Latvia. (2020). Statistical Yearbook of Latvia 2019. Riga, $228 \mathrm{p.}$

4. CSDD - Vehicle statistic (2020). Retrieved: https://www.csdd.Iv/transportlidzekli/registretotransportlidzeklu-skait Access: 19.01.2020.

5. CSDD - Vehicle by manufacturer (2020). Visi transportlidzekli, 1900 - 2020, pec razotaja (All Vehicles from 1900 until 2020, by Manufacturer). Retrieved: https://www.csdd.Iv/transportlidzekli/transportlidzeklivizualizacija. Access: 10.01.2020.

6. Economic Commission for Europe, Inland Transport Committee (2015). Transport Developments in the European Union Transport Developments, provisional agenda. Geneva, 20 p.

7. Enterprise Income Tax Law (2018). With amendments of 30.01.2020, entry into force: 12.02 .2020 . Retrieved: https://likumi.Iv/ta/id/292700-uznemumu-ienakuma-nodokla-likums. Access: 06.01.2020.

8. European Commission (2019). Recommendation for a Council Recommendation on the 2019 National Reform Programme of Latvia and Delivering a Council Opinion on the 2019 Stability. Brussels, 8 p.

9. How to Control Mileage and Fuel Consumption of a Car Using GPS (2017). Retrieved: https://www.loccate.com/blog/control-mileage-and-fuel-using-gps/. Access: 18.01.2020.

10. Jarczok-Guzy M. (2017). The Principles of Tax Law Equality in The Context of Direct Taxation. Journal of Economics and Management / 30, pp. 70-84. 10.22367/jem.2017.30.04.

11. Kharevich G.L. (2017). About the Free-Rider Problem in Post-Industrial Society. Interactive science / 9 (19), pp. 73 - 80. doi:10.21661/r-463534. 
12. Law on the Road User Charge (2014). With amendments of 03.04.2019, entry into force: 13.04.2019. Retrieved: https://likumi.Iv/ta/id/185656-autocelu-lietosanas-nodevas-likums. Access: 12.01.2020.

13. Law on the Vehicle Operation Tax and Company Car Tax (2011). With amendments of 28.07.2017, Entry into force: 01.01.2019. Retrieved: https://likumi.lv/ta/id/223536-transportlidzekla-ekspluatacijas-nodokla-unuznemumu-vieglo-transportlidzeklu-nodokla-likums. Access: 18.01.2020.

14. Leontyev A. (2015). Usage of Methods of the Variant Optimization for Evaluation of Rational Taxation Amount (Использование методов вариантной оптимизации при определении рациональной величины налогообложения). V International, scientific and practical conference of young scientists and students' "Time of challenges and opportunities: problems, solutions and prospects", BSA, pp. $178-181$.

15. Ministru kabineta rikojums (Order of the Cabinet of Ministers) Nr. 245 (2017). Par Valsts nodoklu politikas pamatnostadnem 2018.-2021. gadam (On the State Tax Policy Guidelines for 2018-2021 year). Retrieved: https://likumi.Iv/ta/id/291013-par-valsts-nodoklu-politikas-pamatnostadnem-2018-2021-gadam. Access: 14.01.2020.

16. Natural Resources Tax Law (2006). With amendments of 14.11.2019, Entry into force: 01.01.2020. Retrieved: https://likumi.Iv/ta/id/124707-dabas-resursu-nodokla-likums. Access: 12.01.2020.

17. On Excise Duties (2004). With amendments of 17.10.2019, entry into force: 19.11.2019. Retrieved: https://likumi.Iv/ta/id/81066-par-akcizes-nodokli. Access: 16.01.2020.

18. On Personal Income Tax (1994). With amendments of 21.03.2019, entry into force: 16.04.2019. https://likumi.Iv/ta/id/56880-par-iedzivotaju-ienakuma-nodokli. Access: 14.01.2020.

19.Petrol Availability Rating: Latvia at the Tail End Once Again. (2019). Retrieved: https://lv.sputniknews.ru/infographics/20190804/12175310.html. Access: 18.01.2020.

20. Regulations Regarding Recycling of End-of Life Vehicles and Environmental Requirements Determined for Treatment Facilities (2011). With amendments of 12.03.2019, Entry into force: 15.03.2019. https://likumi.lv/ta/id/226333-noteikumi-par-nolietotu-transportlidzeklu-parstradi-un-apstradesuznemumiem-noteiktajam-vides-prasibam. Access: 08.01.2020.

21.Sproge, I. (2010). Nodoklu politika ekonomikas attistibas mainigajos apstaklos (Tax Policy Under Changing Conditions of Economic Development). Promocional thesis, University of Latvia, 378 p.

22. Value Added Tax Law (2013). With amendments of 28.11.2019, entry into force: 01.01.2020. Retrieved: https://likumi.lv/ta/id/253451-pievienotas-vertibas-nodokla-likums. Access: 14.01.2020.

23. Verovska, L., Leontyev, A. (2017). Use of the Tax Prism Method When Forming Tax Part of the Budget. Economics and Culture, ISSN 2256-0173, DOI: https://doi.org/10.1515/jec-2017-0012. ECONOMICS AND CULTURE 14(1), pp. 128 - 135

24. Verovska, L., Leontyev, A. (2015). Using of Variant Optimization Methods for Determination of Rational Taxation Amount. XVIII International Scientific and Practical Conference "Taxes: Theory and Practice 2015". Republic Czech, Brno, Akademie STING, 7 p.

25. Za jeden vikend a zdarma. Vyvojari spustili system, za ktery chtel stat utratit 400 milionu (For One Weekend and Free. Developers Launched a System for Which the State Wanted to Spend 400 Million) (2020). Retrieved: https://www.novinky.cz/ekonomika/clanek/vyvojari-predstavili-system-zdarma-za-ktery-chtel-stat-utratit400-milionu-chybi-mu-jedina-funkce-40311233. Access: 28.01.2020. 